\title{
MABBAKKANG TRADITION AND ITS' EFFECTS ON HEALTH OF VILLAGERS OF BACU BACU PUJANANTING BARRU: A QUALITATIVE STUDY
}

\author{
Fiqriatul Hidayah ${ }^{1}$, Nuurhidayat Jafar ${ }^{2}$, Silvia Malasari ${ }^{3}$ \\ 1,2,3 Nursing Study Program, Universitas Hasanuddin Makassar \\ email: fiqri_atul@yahoo.com
}

\begin{abstract}
Introduction: Indonesia is an archipelago country that has a diversity of race, culture and customs. Not infrequently customs that are believed by some to be not only a positive impact, but sometimes have a negative impact, especially in health problems. To identify Mabbakkang indigenous phenomenon and its effect on the health of the communities in the District BacuBacu, Pujananting Barru. Methode: Type of studi isQualitative research (phenomenology) was performed on 9 participants who have experience in custom undergo Mabbakkang through interview techniques in-depth interviews and data were analyzed by thematic analysis the technique developed by Colaizzi. Result: This study resulted in 7 themes on a custom implementation Mabbakkang ie execution time, the implementation, a series of execution, people involved, dietary restrictions, reason, and the consequences of breaking taboos. Conclusions: This study shows that a custom implementation Mabbakkang is one tradition that is held each year as a condition for the perfection of a child-Bacu-Bacu village communities and give effect on the health of the communities in the District Bacu Bacu-Pujananting Barru if breaking taboos.
\end{abstract}

Key words : Indigenous Mabbakkang, tradition, health

\section{PENDAHULUAN}

Budaya merupakan pengetahuan yang dipelajari dan disebarkan mengenai adat tertentu dengan nilai, kepercayaan, aturan perilaku dan praktek gaya hidup yang menjadi acuan bagi kelompok tertentu dalam berfikir dan bertindak dengan cara yang terpola (Smeltzer \& Bare, 2001). Budaya merupakan pengetahuan yang dipelajari dan disebarkan sehingga menjadi sebuah petunjuk bagi seseorang dalam berfikir, bersikap dan bertindak sehingga menjadi suatu pola yang mengepresikan siapa mereka dan diturunkan dari satu generasi ke generasi berikutnya (Smeltzer \& Bare, 2001).

Manusia dalam berinteraksi pada komunitas dilandaskan dengan norma, nilai, serta kebiasaan turun temurun yang disebut tradisi. Tradisi atau kebiasaan diartikan sebagai sesuatu budaya atau kebiasaan yang dilakukan sejak lama dan menjadi bagian kehidupan suatu masyarakat, dimana budaya ini diteruskan dari satu generasi kegenerasi berikutnya (Media, 2014). Tradisi dalam pelaksanaanya yang diturunkan dari generasi sebelumnya, tidak hanya memberikan dampak positif saja namun juga memberikan dampak negatif bagi masyarakat (Sutardi, 2006).

Berdasarkan beberapa hasil penelitian mengenai budaya dan kesehatan, terkadang budaya yang dianut bertolak belakang dengan dunia kesehatan. Faktor determinan budaya kesehatan dalam penularan penyakit TB paru seperti budaya Begibung (makan bersama dalam satu nampan) pada masyarakat di Lombok Barat NTB, dapat memungkinkan penularan penyakit TB. Budaya papah makan balita, meminum air bekas Kiai dan menggosok gigi menggunakan bata merah bersama dapat menjadi 
faktor terjadinya penyakit TB (Pratiwi, Roosihermiatie, \& Hargono, 2012).

Pada masyarakat Baduy, selama masa nifas tidak diperkenankan menggunakan pembalut dan pakaian dalam. Sehingga, darah nifas yang keluar hanya dibersihkan menggunakan kain samping yang dikenakannya. Kain samping yang digunakan sebagai media menyeka darah nifas beresiko terhadap kesehatan alat reproduksi mengingat kontaminasi bakteri maupun parasit beresiko terhadap kesehatan alat reproduksi. Perilaku lain yang dipengaruhi oleh budaya pada masyarakat Baduy khususnya ibu postpartum yaitu tidak diperbolehkan cuci rambut yaitu 40 hari setelah masa nifas (Ipa, Prasetyo, \& Kasnodiharjo, 2016).

Salah satu dampak negatif dari tradisi terjadi ketika perayaan Idul Fitri, yang terjadi pada masyarakat Desa Bacu-bacu. Desa Bacu-bacu merupakan salah satu desa yang terletak di Kecamatan Pujananting Kabupaten Barru Sulawesi Selatan, memiliki berbagai bentuk kebudayaan dan salah satunya adalah tradisi adat Mabbakkang. Mabbakang merupakan suatu tradisi yang biasa dilakukan masyarakat Bacu-bacu dua minggu pasca lebaran Idul Fitri. Dalam pelaksanaanya masyarakat tiga dusun yang berada di Desa Bacubacu tidak diperkenankan untuk mengonsumsi makanan tertentu seperti ikan dan daging, tidak boleh bekerja kecuali tenaga pengajar, dan di dusun Ampiri warga tidak diperbolehkan mandi menggunakan sabun yang berakibat pada perilaku personalhygiene masyarakat Desa Bacu-bacu Kecamatan Pujananting Kabupaten Barru.

Indonesia merupakan negara kepulauan yang memiliki keanekaragaman suku, budaya dan adat istiadat yang berbeda-beda pada setiap daerah. Tidak jarang adat istiadat yang diyakini oleh sebagian orang tidak hanya memberikan dampak positif namun kadangkala memberikan dampak negatif bagi mereka terutama dalam masalah kesehatan. Penelitian ini bertujuan untuk mengidentifikasi fenomena adat Mabbakkang dan pengaruhnya terhadap kesehatan pada masyarakat Desa Bacu-bacu Kecamatan Pujananting Kabupaten Barru.

\section{METODE}

Penelitian ini menggunakan metode penelitian kualitatif dengan pendekatan fenomenologi. Partisipan dalam penelitian ini adalah masyarakat Desa Bacu-bacu Kecamatan Pujananting Kabupaten Barru yang berjumlah 9 orang. Pemilihan partisipan pada penelitian ini dipilih menggunakan metode snowball sampling.

\section{HASIL}

Partisipan dalam penelitian ini berjumlah 9 orang. Karakteristik partisipan dapat dilihat dalam Tabel 1.

\begin{tabular}{ccccc}
\hline $\begin{array}{c}\text { Kode } \\
\text { Partisipan }\end{array}$ & Usia & Bahasa & $\begin{array}{c}\text { Lama tinggal di } \\
\text { Desa Bacu-bacu }\end{array}$ & $\begin{array}{c}\text { Lama mengikuti Adat } \\
\text { Mabbakkang }\end{array}$ \\
\hline P1 & 34 tahun & Indonesia & Sejak lahir & Sejak lahir \\
P2 & 45 tahun & Indonesia & Sejak lahir & Sejak lahir \\
P3 & 31 tahun & Indonesia & Sejak lahir & Sejak lahir \\
P4 & 29 tahun & Indonesia & Sejak lahir & Sejak lahir \\
P5 & 40 tahun & Bugis & Sejak lahir & Sejak lahir \\
P6 & 41 tahun & Indonesia & Sejak lahir & Sejak lahir \\
P7 & 40 tahun & Bugis & Sejak lahir & Sejak lahir \\
P8 & 31 tahun & Bugis & Sejak lahir & Sejak lahir \\
P9 & 29 tahun & Bugis & Sejak lahir & Sejak lahir \\
\hline
\end{tabular}

Tabel 1. Karakteristik partisipan. 
Penelitian ini menghasilkan tujuh tema utama yaitu: waktu pelaksanaan adat Mabbakkang, tempat pelaksanaan adat Mabbakkang, rangkaian pelaksanaan adat Mabbakkang, orang yang terlibat pada pelaksanaan adat Mabbakkang, pantangan selama menjalani adat Mabbakkang, alasan megikuti pelaksanaan adat Mabbakkang, serta akibat dari melanggar pantangan adat Mabbakkang.

\section{Waktu pelaksanaan adat Mabbakkang}

Partisipan dalam penelitian ini mengatakan Waktu pelasanaan adat Mabbakkang yaitu dimulai sejak hari Jum'at selama dua minggu pada bulan delapan setiap tahun. Berikut adalah pernyataan partisipan:

"dua minggu toh, Jum'at dimulai Jum'at diakhiri setiap bulan Agustus. pokoknya setiap tahun itu dek Mabbakkang orang" (P1), "iya Mabbakkang orang dua minggu, setiap tahun orang disini Mabbakkang. Bulan Agustus biasanya Mabbakkang orang disini" (P4).

\section{Tempat pelaksanaan adat Mabbakkang}

Masyarakat menyatakan bahwa rumah anak yang akan dibakkang mejadi tempat pelaksanaan adat Mabbakkang. Hal ini sesuai dengan pernyataan beberapa partisipan sebagai berikut:

"... dirumah yang ada anak yang mau dibakkang..." (P1), "lima $i$ engka ana'ta lao ko maneng'i ro mapassibola untuk maccani-cani ato mabakkang asenna" (itu kelima anaknya berkumpul dirumah untuk mabbakkang) (P7).

\section{Rangkaian pelaksanaan adat Mabbakkang}

a. Menyanyi

Kebanyakan partisipan mengatakan bahwa salah satu rangkaian pelaksanaan adat Mabbakkang yaitu menyanyi. Hal tersebut sesuai dengan pernyataan yang disampaikan oleh beberapa partisipan sebagai berikut:

"...ada anak yang mau dibakkang ada nyanyinya" (P1), "ada nyanyinyanyinya juga..." (P2), "engka yaseng elong-elong yaregga parello doang..." (dinyanyikan dan dibacakan doa) (P5).

b. Ma'cani-cani (menaruh sirih yang ditumbuk kedahi)

Salah satu rangkaian dari pelaksanaan adat Mabbakkang yaitu ma'cani-cani( menaruh sirih yang ditumbuk kedahi) kepada anak yang akan dibakkang. Hal ini sesuai dengan pernyataan beberapa partisipan sebagai berikut:

"kalo kampung kalin bilangnya ma'cani-cani yang dikasih sirih didahi..." (P1), "anak yang mau dibakkang dipakai sirih didahina" (P2), "anak-anak dicani-cani menggunakan daun sirih" (P5).

c. Membuat kue tradisional

Rangkaian lain dari pelaksanaan adat Mabbakkang yaitu membuat kue tradisional seperti kue be'da dan songkolo. Hal ini sesuai dengan pernyataan beberapa partisipan sebagai berikut:

"...biasa bikin-bikin kue tradisi lah kue be'da" (P2), "sibawa iyebburengi anu anre ade mabbe'da" (dibikinkan makanan khas dikampung ini membuat kue be'da) (P9), "Massoko' toni” (dibuat songkolo) (P5) (P8).

\section{d. Potong ayam}

Kebanyakan partisipan mengatakan bahwa potong ayam dilaksanakan pada saat hari terakhir Mabbakkang. Hal tersebut sesuai dengan pernyataan yang disampaikan oleh beberapa partisipan sebagai berikut:

"iya potong ayam,... karena selesai mi toh, semacam ucapan syukur karena sudah dibakkang anaknya" (P1), Nakku purani ye sepuloh lima essona igerekengni manu" (apabila sudah lima belas hari dipotongkan ayam) (P5). 


\section{Orang yang terlibat pada pelaksanaan adat Mabbakkang}

a. Anak yang belum pernah dibakkang

Beberapa partisipan mengungkapkan bahwa seorang anak yang berasal dari bacu-bacu diharuskan melakukan Mabbakkang. Hal ini sesuai dengan pernyataan beberapa partisipan sebagai berikut:

"misalnya to jaji inne tahun'nge ee depa'ta pura mabbakkang, na ta mabbakkang" (Misalnya kita lahir tahun ini baru belum melakukan mabbakkang, jadi kita mabbakkang tahun ini)(P7), "iye mabbakkang yakka perrikeng $i$ ana ye depa e naengka naccoe mabbakkang"(ini kegiatan mabbakkang diwajibkan bagi anak yang belum pernah ikut mabbakkang (P8).

\section{b. Memiliki niat dan nazar}

Beberapa partisipan menyatakan bahwa masyarakat yang agar dapat dibakkang kembali dapat mengikuti adat Mabbakkang kembali. Hal ini sesuai dengan pernyataan beberapa partisipan sebagai berikut:

"kalo ada orang tua yang nazar toh mau dibakkang kembali."(P2), "tapi ada mentong itu biasanya kalo ada niatnya toh bilang mau dibakkang kembali biar orang besar, biar orang tua"(P4)(P8).

\section{c. Masyarakat desa yang telah dibakkang}

Adapula partisipan yang mengatakan bahwa diwajibkan pula mengikuti mabbakkang namun tidak perlu melaksanakan rangkaian pelaksanaan mabbakkang. Hal ini sesuai dengan beberapa pernyataan partisipan sebagai berikut:

"Seluruh desa, seluruh masyarakat di desa, biar yang kecilkecil"(P1) (P70 (P9), "semuanya nak, satu desa ikut semua. Tua yang muda ikut semua" (P2).

\section{d. Masyarakat Desa Bacu-bacu yang sedang merantau}

Selain itu ada pula partisipan yang mengungkapkan bahwa tidak masalah apabila tidak mengikuti mabbakkang namun apabila memiliki anak yang belum pernah dibakkang diharuskan pulang ke desa untuk dilakukan ritual mabbakkang. Sesuai dengan pernyataan salah satu partisipan sebagai berikut:

“...pulang kalo ada anaknya yang masih kecil dan belum dibakkang” (P1), "lessuni ri kampung na ri nih na de'pa na mabakkang, nappai i pabakkang'i kan nappai engka ri ni" (jadi ketika dia pulang di sini baru dia belum pernah mabbakkang, baru dilakukan mabbakkang karena dia baru ada disini) (P7).

\section{Pantangan selama menjalani adat Mabbakkang}

a. Makanan

Beberapa partisipan mengungkapkan bahwa masyarakat yang tinggal didusun Ammerung dan Batu Lappa tidak diperbolehkan mengonsumsi makanan seperti telur, daging, makanan yang pedas dan bergetah. Hal ini sesuai dengan pernyataan beberapa partisipan sebagai berikut:

"tidak boleh makan makan pedas, yang bergetah, telur, daging, yang anu juga nangka, yang bergetah"(P1), "yang nda boleh dimakan banyak, yang pedispedis, nangka, sukun, telur, pisang yang mentah juga nda dimakan"(P2).

Sementara itu terdapat pula partisipan yang mengatakan bahwa masyarakat yang tinggal didusun Ampiri tidak diperbolehkan untuk mengonsumsi segala jenis makanan kecuali ikan bete-bete. Hal ini sesuai dengan beberapa pernyataan partisipan sebagai berikut:

"de,naweddingki manre bale. Bale bete-bete, mi nawedding yanre"(tidak diperbolehkan makan ikan, hanya ikan bete-bete saja yang diperbolehkan dikonsumsi.)(P5), "itu yang pantangannya yang pedas, pahit, dengan ikan ikan yang besar hanya ikan kecil saja yang bisa ikan bete- 
bete telur, ayam, daging, supermie tidak bisa" (P6).

\section{b. Pekerjaan}

Beberapa partisipan mengungkapkan bahwa tidak diperbolehkan untuk pergi kesawah dan kekebun. Hal ini sesuai dengan pernyataan beberapa partisipan sebagai berikut:

"iya nda kesawah orang begitu juga, pokoknya libur dua mingguan nda bisa kerja dirumah saja makan saja"(P6), "mappamali, denawadding makareso, denawadding lao madare, magalung, biassanna monro mi mapakue manre mi, tiap taun mabbakkang orang" (pamali, tidak bisa kerja, tidak bisa pergi kekebun, kesawah, biasanya tinggal saja begini makan, setiap tahun mabakkang orang) (P7).

\section{c. Mandi tidak menggunakan sabun}

Beberapa partisipan yang berasal dari dusun Ampiri mengungkapkan bahwa pada saat pelaksanaan adat Mabbakkang warga dusun Ampiri mandi namun tidak menggunakan sabun, pasta gigi dan sampo. Hal ini sesuai dengan pernyataan beberapa partisipan sebagai berikut:

"iya, tidak pake sabun tidak bisa juga apakai odol dan sampo"(P6), "iye, cemme mi, tapi dena pake sabung" (iya, mandi saja tapi tidak pake sabun) (P7)

Selain itu partisipan dusun Ampiri mengatakan bahwa mereka hanya mandi menggunakan air saja. Hal tersebut sesuai dengan pernyataan beberapa partisipan sebagai berikut:

"de'ki nawedding masabung..., jaji cemme wae biasami nawedding"(tidak bisa juga menggunakan sabun dan bedak , jadi Cuma mandi menggunakan air biasa saja) (P1), ", kita juga mandi mandi air saja tidak boleh yang lain selain itu" (P6).

\section{d. Tidak memperindah dirinya Partisipan yang berasal dari}

dusun Ampiri mengungkapkan bahwa pada saat pelaksanaan adat Mabbakkang warga dusun Ampiri tidak diperbolehkan memakai bedak. Hal ini sesuai dengan pernyataan salah satu partisipan sebagai berikut:

"naweddingki mabeddak"(tidak memakai bedak) (P5).

\section{Alasan mengikuti pelaksanaan adat Mabbakkang}

a. Sejak dahulu

B eberapa partisipan mengungkapkan bahwa alasan mereka tetap melaksanakan ada mabbakkang adala karena adat ini sudah turun temurun sejak dahulu ada. Hal ini sesuai dengan pernyataan beberapa partisipan sebagai berikut:

"Karena adat, dari dulu. Karena turun temurun"(P1)(P2)(P4)(P8)(P9).

\section{b. Takut dengan dampak yang ditimbulkan}

Hasil penelitian ini teridentifikasi menjadi satu kata kunci yaitu alasan masyarakat masyarakat tetap melaksanakan adat Mabbakkang adalah takut dengan pamali. Hal ini sesuai dengan pernyataan beberapa partisipan sebagai berikut:

"apabila kita melanggar diri kita sendiri akan terkena. Jadi makanya kita masyarakat setempat ini harus pamali."(P6), "iya i pamali maneng $i$ kalo de'na jamai" (iya, pamali semua, kalau tidak dikerjakan)(P7) (P8).

\section{c. Sebagai syarat kesempurnaan seorang anak \\ B eberapa partisipan} mengungkapkan bahwa alasan mereka tetap melaksanakan ada mabbakkang adala karena adat ini menjadi syarat kesempurnaan seorang anak. Hal ini sesuai dengan pernyataan beberapa partisipan sebagai berikut:

"yapi sempurna,i ana-ana,e akku pura,i mabbakang."(Anak-anak telah dikatakan sempurna apabila telah ikut melakukan prosesi mabbakkang.) (P5), "jaji yasengi sempurna ero ana- 
anae engka e ku kampong akku purai ibakkang."(jadi dikatakan sempurna itu anak-anak dikampung ini apabila telah mengikuti mabbakkang.)(P8).

\section{Akibat melanggar adat Mabbakkang}

a. Gatal-gatal

Hasil penelitian ini teridentifikasi menjadi satu kata kunci yaitu akibat melanggar pantangan selama melaksanakan adat Mabbakkang adalah gatal-gatal akibat mandi menggunakan sabun. Hal ini sesuai dengan pernyataan beberapa partisipan sebagai berikut:

" akku engka makkuro, makate manengi alalena, narekko cemme pake sabungi waktu mabbakkang"(kalau ada yang seperti itu, badannya bisa gatalgatal apabila menggunakan sabun ketika mabbakkang) (P5), "contohnya kalo kita memakai sabun, tetap mandi memakai sabun saat mabbakkang begitu kita akan terkena bintik-bintik gatal-gatal"(P6).

\section{PEMBAHASAN}

\section{Waktu pelaksanaan adat Mabbakkang}

Hasil penelitian ini menunjukkan bahwa waktu pelaksanaan adat Mabbakkang yang dilakukan oleh masyarakat Desa Bacu-bacu adalah setiap tahun pada bulan delapan yang dimulai sejak hari Jum'at selama dua minggu. Namun masyarakat adat umat Kaharingan khususnya apabila hendak melaksanakan ritual, entah dibidang kehidupan maupun kematian memakan waktu beberapa hari yang sangat menguras tenaga, pikiran dan waktu. Hal tersebut dikarenakan kerugian yang disebabkan oleh pangulu adat yang meninggalkan pekerjaan mereka disawah dan ladang selama berhari-hari agar kegiatan ritual terselenggara dengan baik (Susanto, 2007). Mengatakan bahwa ritual merupakan perilaku yang dilakukan secara berulang (repetitive) secara rutin, terjadwal dan ditentukan mengikuti suatu siklus waktu. Salah satu implikasi penting dari ritual yang terjadi secara berkala yaitu tidak diatur dan didikte oleh situasi, melainkan melalui apa yang dipandang benar (Manafe, 2011). Waktu pelaksanaan upacara adat merupakan saat-saat tertentu yang dirasakan tepat untuk melangsungkan upacara. Dalam upacara rutin yang diselenggarakan setiap tahun biasanya terdapat patokan dari waktu pelaksanaan upacara yang lampau (Koentjaraningrat, 2009).

\section{Tempat pelaksanaan adat Mabbakkang}

Hasil penelitian ini menunjukan bahwa tempat pelaksanaan adat Mabbakkang yaitu dirumah anak atau orang yang ingin dibakkang, dimana pada hari terakhir Mabbakkang tetua desa akan memulai ritualnya. Sedangkan bagi masyarakat Kajang tempat pelaksanaan ritual adat akkattere' berbentuk persegi empat menyrupai ka'bah yang terdapat di Masjidil Haram Tanah Suci Almukarramah Mekkah Saudi Arabia. Tempat tersebut dibungkus dengan menggunakan kelambu putih yang menyimbolkan kesucian dari manusia yang dihakikah (dikattere') (Widiawanti, 2015). Tempat yang digunakan untuk melaksanakan suatu upacara biasanya adalah tempat keramat atau bersifat sakral atau suci, tidak setiap orang dapat mengunjungi tempat tersebut. Tempat itu hanya digunakan oleh orang-orang yang berkepentingan, dalam hal ini adalah orang yang terlibat dalam pelaksanaan upacara seperti pemimpin upacara (Koentjaraningrat, 2009).

\section{Rangkaian pelaksanaan adat Mabbakkang}

Menyanyi merupakan salah satu dari rangkaian pelaksanaan adat Mabbakkang bertujuan untuk memohon perlindungan dan keselamatan yang dilakukan oleh tetua adat di rumah warga yang 
anaknya dibakkang. Pada pelaksanaan pesta akkattere sepanjang malam semua masyarakat menyatu dalam kebersamaan yang diiringi dengan nyanyian-nyanyian spiritual dan genderang (Widiawanti, 2015). Selama kenduri dilaksanakan doa bersama yang dipimpin oleh seorang kaum yang bertujuan untuk memohon keselamatan untuk ibu dan bayi serta masyarakat desa (Retnoningsih, 2014).

Rangkaian lain pada pelaksanaan adat Mabbakkang yaitu ma'cani-cani atau menaruh daun sirih yang telah ditumbuk didahi anak yang dibakkang. Tradisi Royong, dimana beberapa bahan dan perlengkapan upacara disipakan sanro membuat ramuan obat dengan bahan daun sirih untuk dijadikan obat penutup ubun-ubun sibayi (Sulkarnaen, 2010).

Rangkaian pelaksanaan adat Mabbakkang selanjutnya adalah membuat kue tradisional yaitu kue be'da dan songkolo serta memotong ayam. Penjamuan tidak akan lengkap tanpa adanya kue-kue tradisional sebagai pencuci mulut para peserta upacara dikarenakan kue-kue tradisional seperti sokko sudah menjadi tradisi masyarakat Bugis. Padi merupakan makanan pokok manusia salah satunya bagi masyarakat Bugis, sehingga pengadaan nasi ketan (sokko) sangatlah penting dan memiliki makna tersendiri dalam setiap upacaraupacara masyarakat Bugis pada umumnya karena masyarakat Bugis mengganggap sokko dapat bertahan lama dan memberikan energi atau kekuatan lebih lama (Firmansyah, 2012). Membuat kue-kue tradisional ini dilakukan pada hari terakhir pelaksanaan adat Mabbakkang yang dibantu oleh tetangga sekitar untuk membantu memasak yang merupakan wujud dari kerjasama antara sesama warga desa. Rangkaian upacara kehamilan sampai dengan kelahiran di Kabupaten Klaten bahwa salah satu wujud dari kerjasama atara masyarakat terlihat. Dimana ibu-ibu membagi tugas, ada yang mengurus beras, janganan, dan ayam untuk membuat tumpeng robyong (Retnoningsih, 2014).

\section{Orang yang terlibat pada pelaksanaan adat Mabbakkang}

Hasil penelitian menunjukan bahwa orang yang terliba dalam pelaksanaan adat Mabbakkang berasal dari masyarakat Desa Bacubacu dan bukan masyarakat Desa Bacu-bacu. Dimana masyarakat Desa Bacu-bacu terdiri dari anak kecil yang belum pernah dibakkang, masyarakat yang ingin dibakkang kembali, masyarakat yang telah dibakkang, dan masyarakat desa bacu-bacu yang sedang merantau. Sedangkan untuk masyarakat yang bukan berasal dari Desa Bacu-bacu adalah orang yang berasal dari luar desa namun pada saat adat Mabbakkang sedang terlaksana berada di Desa Bacu-bacu, sehingga mereka diharuskan untuk mengikuti adat Mabbakkang bersama dengan masyarakt Desa Bacu-bacu. Orang yang terlibat dalam pelaksanaan upacara adalah mereka yang bertindak sebagai pemimpin jalannya upacara dan beberapa orang yang paham dalam ritual upacara adat. 9

\section{Pantangan selama menjalani adat Mabbakkang}

Beberapa jenis bahan makanan seperti telur, daging, makanan pedas, serta yang bergetah seperti nangka dan pisang muda menjadi bahan makanan yang menjadi pantangan untuk dikonsumsi oleh masyarakat dusun Ammerung dan Batu Lappa. Sedangkan untuk masyarakat yang menetap didusun Ampiri, hampir seluruh jenis makanan tidak diperboleh untuk dikonsumsi kecuali ikan bete-bete. Ikan bete-bete sendiri merupakan sejenis ikan kecil yang biasa di konsumsi oleh masyarakat desa Bacu-bacu.

Berdasarkan hasil penelitian ini, partisipan pantangan makan-makanan tertentu. Makanan yang dipantang ada yang memang dianjurkan untuk 
dikonsumsi namun ada juga yang tidak boleh dikonsumsi. Pantangan atau tabu adalah suatu larangan untuk mengonsumsi jenis makanan tertentu, karena terdapat ancaman bahaya atau hukuman terhadap barang siapa yang melanggarnya. Sebagian besar informan utama mengatakan bahwa ibu hamil yang berada di Tangerang Selatan memiliki pantangan makanan tertentu yang sebaiknya tidak dikonsumsi seperti makanan pedas dan telur. Hal ini dikarenakan mereka beranggapan jika mengonsumsi telur atau baso bayi yang dikandung akan besar dan bisul. Padahal terlur memiliki kandungan energi dan protein yang baik untuk kecukupan gizi ibu hamil.14

Pantangan selanjutnya yang tidak boleh dilakukan oleh masyarakat desa Bacu-bacu yaitu pergi kesawah dan kekebun selama pelaksanaan adat Mabbakkang. Namun selain dari pergi kesawah dan kekebun, masyarakat Desa Bacu-bacu diperbolehkan beraktifitas seperti biasa misalnya mengajar, bersekolah dan berdagang. Pantangan ini sekilas mirip dengan pantangan dalam tradisi Nyepi yang biasa dilaksanakan oleh masyarakat Bali, namun masyarakat Bali dalam melaksanakan Nyepi segala interaksi tidak bisa berjalan, tidak bisa berkomunikasi dengan orang lain, tidak bisa melakukan aktivitas seperti biasa dan apabila terdapat masyarakat yang melanggar peraturan yang telah ditetapkan makaakan dikenakan denda pada siapapun yang melanggar. 15

Pantangan berikutnya yang tidak boleh dilakukan oleh masyarakat Bacu-bacu khususnya bagi masyarakat didusun Ampiri yaitu tidak diperbolehkan untuk mandi menggunakan sabun, sampo, serta pasta gigi begitupula dengan menggunakan bahan-bahan alami sehingga masyarakat dusun Ampiri hanya menggunakan air untuk mandi. Hal ini terjadi setiap tahun pada saat pelaksanaan Mabbakkang sejak mereka baru dilahirkan. Alasan masyarakat terus mempertahankan pantangan pada tradisi ini dikarenakan mereka takut dengan akibat yang akan terjadi apabila mereka mandi menggunakan sabun yaitu gatal-gatal disekujur tubuh.

Tradisi mandi syafar pada masyarakat Desa Sungai Buluh, kecamatan Singkep Barat Kabupaten Lingga Provinsi Riau bahwaa pada saat pelaksanaannya tokoh agama berdiri disamping tempayan yang telah berisi air dan rendaman wakaf sambil membaca salawat sebanyak 3 kali dan dilanjutkan penyiraman pada setiap orang. Tujuan dilaksanakan mandi shafar adalah untuk menghindarkan bala yang bersifat fisik seperti terhindar dari penyakit ta'un atau penyakit tahunan seperti demam, diare dan sebagainya.16

Pantangan selanjutnya bagi masyarakat dusun Ampiri adalah memperindah diri dengan menggunakan bedak, wewangian seperti parfum dan pakaian baru. Hal ini dikarenakan masyarakat takut pamali sehingga tidak diperbolehkan menggunakan pakaian yang terlalu mencolok dan sembarangan selama pelaksanaan adat Mabbakkang. Makna simbolik ritual ngobur tamoni pada masyarakat Sumenep. Ritual ngobur tamoni merupakan prosesi penguburan tali pusar bayi oleh ayah dari bayi yang baru lahir tersebut. Salah satu ciri dalam ritual tradisi ini adalah merias wajah dari orang yang akan mengubur ari-ari tersebut atau dalam sitilahnya adalah "a gincu, a cellak, a bedda' popor". 17

\section{Alasan mengikuti pelaksanaan adat Mabbakkang}

Alasan masyarakat mengikuti adat Mabbakkang yaitu sebagai syarat kesempurnaan seorang anak agar memproleh keselamatan dan ucapan syukur orang tua atas kelahiran sang anak. Ritual attompolo merupakan ritual akikah sebagai tanda beryukur kepada tuhan atas kelahiran anak dan cucu mereka, sekaligus menyerakan 
tanda terimakasih kepada dukun beranak (sanro pammannakkang) atau bidan desa yang telah menangani kelancaran proses persalinan anak dan menantu mereka.13

Alasan berikutnya yang diutarakan oleh masyarakat Desa Bacubacu adalah untuk melestarikan tradisi turun-temurun peninggalan dari nenek moyang sejak dahulu. Pelaksanaan upacara tradisional dilakukan sebagai wujud penghormatan atas budaya warisan nenek moyang yang turun temurun harus dilestarikan sehingga dapat memupuk rasa persaudaraan dan menumbuhkan nilai-nilai luhur bagi masyarakat. 9

Selain sebagai syarat kesempurnaan seorang anak dan melestarikan tradisi, alasan lain yang diutarakan oleh masyarakat desa Bacu-bacu adalah untuk menghindari dampak yang terjadi apabila tidak melaksanakan adat mabbakkang. Upacara tradisional dilaksanakan bertujuan untuk menghindari hal-hal yang tidak diinginkan dan dijauhkan dari malapetaka yang dikhawatirkan akan menimpa masyarakat apabila tidak dilaksanakan.9

\section{Akibat melanggar adat Mabbakkang}

Alasan masyarakat dusun Ampiri tetap mempertahankan tradisi mereka yaitu mandi tidak menggunakan sabun salah satunya adalah menghindari mereka dari penyakit gatal-gatal apabila mereka mandi menggunakan sabunTradisi mandi syafar pada masyarakat Desa Sungai Buluh, kecamatan Singkep Barat Kabupaten Lingga Provinsi Riau bahwa tujuan dilaksanakan mandi shafar adalah untuk menghindarkan bala yang bersifat fisik.16 Pelasanaan upacara tradisional termasuk dalam golongan adat yang tidak mempunyai akibat hukum, namun apabila tidak dilakukan oleh masyarakat maka menimbulkan rasa khawatir akan terjadi seusatu yang buruk menimpa dirinya. 9
Kebersihan diri atau disebut juga dengan personal hgiene merupakan suatu pengetahuan tentang usahausaha kesehatan perorangan untuk memelihara kesehatan diri sendiri, memperbaiki dan meningkatkan nilai kesehatan serta mencegah timbulnya penyakit. Terdapat beberapa faktor yang mempengaruhi pelaksanaan personal hygiene diantaranya adalah citra tubuh, praktik sosial, status sosial ekonomi, pengetahuan, budaya, pilihan pribadi dan kondisi fisik. Budaya menjadi salah satu faktor yang mempengaruhi pelaksanaan personal hygiene dikarenakan, sebagian masyarakat beranggapan apabila sesorang mengalami sakit tertentu maka tidak diperbolehkan mandi. Personal hygienedilaksanakan bertujuan untuk tetap menjaga kebersihan tubuh, yang salah satunya dapat dilakukan dengan mandi. Mandi bermanfaat untuk memelihara kesehatan, menjaga kebersihan, serta mempertahankan penampilan agar tetap rapi2009. Namun ,apabila seseorang tidak melaksanakannya akan terjangkit penyakit kulit. Penyakit kulit mudah menginfeksi apabila tidak menjaga kebersihan terutama kebersihan pribadi. Menjaga kebersihan pribadi dapat memutuskan mata rantai penularan agen penyebab penyakit kulit dari tempat hidupnya. Penyakit kulit akan lebih mudah menyerang apabila imun seseorang sedang menurun. 19

\section{SIMPULAN}

Penelitian ini memperlihatkan bahwa pelaksanaan adat Mabbakkang merupakan salah satu tradisi yang dilaksanakan setiap tahunnya sebagai syarat kesempurnaan seorang anak bagi masyarakat Desa Bacu-Bacu dan berpengaruh terhadap kesehatan apabila melanggar pantangan selama pelaksanaan adat Mabbakkang.

\section{DAFTAR PUSTAKA}

Smeltzer, S. C., \& Bare, B. G. (2001). Bruner and suddart's textbook of medical-surgical. 
Philadelphia: Lippincott-Raven Publisher.

Lestari, S., Widodo, \& Sumardino. (2014). Pendekatan kultural dalam praktek keperawatan profesional dirumah sakit jogja international hospital. Jurnal kesmadaska, 1-8.

Media, A. (2014). Melestarikan orisinilitas. Bali: Akar media Indonesia.

Sutardi, T. (2006). Antropologi: mengungkapkan keragaman budaya. Bandung: Setia purna inves.

Pratiwi, N. L., Roosihermiatie, B., \& Hargono, R. (2012). Faktor Determinan Budaya Kesehatan Dalam Penularan Penyakit TB Paru. Buletin penelitian sistem kesehatan, 26-37.

Ipa, M., Prasetyo, D. A., \& Kasnodiharjo. (2016). Praktik Budaya Perawatan Dalam Kehamilan Persalinan dan Nifas Pada Etnik Baduy Dalam. Jurnal Kesehatan Reproduksi, 25-36.

Susanto, A. B. (2007). Masih(kah) Indonesia. Yohyakarta: Kanisius.

Manafe, Y. D. (2011). Komunikasi Ritual pada Budaya Bertani Atoni Pah Meto di TimorNusa Tenggara Timur. Jurnal Komunikasi , 287-298.

Koentjaraningrat. (2009). Pengantar Ilmu Antropologi. Jakarta: Rineka Cipta.

Widiawanti, A. (2015). Simbolisme dalam Sistem Kepercayaan Masyarakat adat Kajang dalam (Ilalang Embayya) di Kecamatan Kajang Kabupaten Bulukumba. Makassar: Universitas Hasanuddin.

Retnoningsih, D. (2014). Kajian Folklor Rangkaian Upacara adat Kehamilan sampai dengan kelahiran Bayi di Desa
Borongan, Kecamatan Polanharjo, Kabupaten Klaten. Yogyakarta: eprints. uny.ac.id.

Sulkarnaen, A. (2010). Tradisi Royong Makassar: Kajian Terhadap Perubahan dari Ritual Keseni Pertunjukan. Depok: lib.ui.ac.id.

Firmansyah. (2012). Nilai-Nilai Solidaritas Sosial dalam Upacara Maccera' Tappareng di Danau Tempe Kabupaten Wajo. Makassar: Universitas Hasanuddin.

Hasanah, D. N., Febrianti, \& Minsarnawati. (2012). Kebiasaan makan menjadi salah satu penyebab kekurangan energi kronis (KEK) pada ibu hamil di poli kebidanan RSI\&A lestari cirendeu tangerang selatan. Kesehatan reproduksi, 91-104.

Werdiani, N. W., Sanjaya, D. B., \& Sudiatmaka, K. (2014). Pelaksanaan Tradisi Nyepi Adat Ditinjau dari Sosio-Budaya dan Religius di Desa Pkraman Palaktiying, Kecamatan Bangil, Kabupaten Bangil. ejournal. undikshas, 1-14.

Aditiya, R. (2015). Tradisi MAndi Safar Desa Sungai Buluh Kecamatan Singkep Barat Kabupaten Lingga Provinsi Kepulauan Riau. Jom Fisip, 1-15.

Abidin, A. Z. (2014). Makna Simbol Ritual Ngobur Tamoni (Studi Etnografi Ritual Ngobur Tamoni di Klurahan Pajagalan, Kecamatan Kota Sumenep, Kabupaten Sumenep). Journal Unair, 76-84.

Potter, P. A., \& Perry, A. G. (2009). Buku Ajar Fundamental Keperawatan: Konsep, Proses dan Praktik Edisi 5. Jakarta: EGC.

Price, S. A., \& Wilson, L. M. (2005). Patofisiologi Konsep Klinis Proses-Proses Penyakit. Jakarta: EGC. 